\title{
PENYULUHAN FAKTOR RISIKO PENYAKIT TIDAK MENULAR DAN PENGGUNAAN MEDIA PIRING ANTI HIPERTENSI PADA KADER POSBINDU PENYAKIT TIDAK MENULAR (PTM) DI DESA CIKUNIR KECAMATAN SINGAPARNA
}

\section{OLEH :}

\author{
Wuri Ratna Hidayani, Nurazijah, Lia Amalia, Ario Wahid Sauma, Iqrar Yanwar Shobah
}

STIKes Respati

(wuri.ratnahidayani@gmail.com )

\section{A. DASAR PEMIKIRAN}

Penyakit tidak menular merupakan penyebab kematian di dunia. Kematian yang disebabkan oleh PTM selain penyakit kardiovaskuler pada tahun 2015 adalah kanker sebesar 8,8 juta orang dan sebanyak 3 juta penyakit pernapasan kronis. (WHO, 2017) Indonesia mengalami beban ganda yaitu selain menanggulangi permasalahan penyakit menular juga menanggulangi penyakit-penyakit tidak menular, dalam penanggulangan penyakit menular belum tuntas muncul permasalahan serius penyakitpenyakit tidak menular yang meningkatkan mortalitas dan morbiditas dalam masyarakat. Kemajuan teknologi selain berdampak positif tetapi juga berdampak negatif yaitu menjadikan malas dalam beraktivitas fisik, paparan radiasi, paparan pencemaran lingkungan, konsumsi makanan instans yang kurang baik bagi kesehatan.

Hal ini dapat memicu penyakit tidak menular seperti hipertensi, stroke, jantung, penyakit kardivaskuler lainnya. Penyakit tidak menular seperti hipertensi sebesar 9,5\% dari jumlah penduduk $\geq 15$ tahun sebanyak 722.329 jiwa, kedua terbanyak penyakit paru obstruktif kronis (PPOK) sebesar $3,7 \%$ dari jumlah penduduk $\geq 30$ tahun sebanyak 508.302 jiwa diikuti diabetes mellitus sebesar 2,1\% dari jumlah penduduk sebanyak 722.329 jiwa. (Depkes RI, 2014) Dinas Kesehatan Jawa Barat (2013) menyatakan bahwa prevalensi penyakit tidak menular salah satunya diabetes mellitus adalah 4,2 \% dengan jumlah prediabet sebesar 7,8\%.(Dinas Kesehatan Provinsi Jawa Barat, 2013)

Berdasarkan data surveilans penyakit tidak menular di Puskesmas Singaparna masih tinggi yaitu hipertensi tahun 2018 sebanyak 144 orang (Puskesmas Singaparna, 2014). Berbagai upaya dilakukan untuk menanggulangi dan upaya preventif peningkatan penyakit tidak menular. STIKes Respati merupakan institusi yang berperan dalam upaya preventif yaitu dalam kegiatan tridharma yang dilakukan oleh dosen program studi Kesehatan Masyarakat salah satunya dengan kegiatan pengabdian masyarakat sebagai rangkaian dari kegiatan penelitian. Kegiatan pengabdian masyarakat berupa kegiatan penyuluhan faktor risiko penyakit tidak menular dan penggunaan media piring antihipertensi pada kader Posbindu PTM di Desa Cikunir Kecamatan Singaparna Kabupaten Tasikmalaya Tahun 2019.

\section{B. TUJUAN}

1. Tujuan Umum:

Meningkatkan derajat kesehatan masyarakat bagi kader posbindu PTM melalui kegiatan yang bersifat promotif dan preventif.

2. Tujuan Khusus:

a. Penyebarluasan informasi untuk meningkatkan pengetahuan kepada Kader Posbindu PTM tentang faktor risiko penyakit tidak menular. 
b. Memberikan informasi kepada Kader Posbindu PTM tentang cara pencegahan hipertensi melalui media promosi kesehatan yaitu piring antihipertensi

c. Meningkatkan pengetahuan dan kesadaran kepada kader Posbindu PTM untuk senantiasa berperilaku hidup sehat menghindari factor risiko penyakit tidak menular salah satunya dengan pemenuhan kebutuhan gizi seimbang sesuai piring antihipertensi sebagai upaya pencegahan terhadap penyakit degeneratif seperti hipertensi.

\section{BENTUK KEGIATAN}

Pengabdian masyarakat ini dengan melakukan penyuluhan kepada kader Posbindu PTM dan peragaan media piring antihipertensi. Lokasi kegiatan ini di Desa Cikunir dengan teknik sampling adalah totality sampling, teknik pengumpulan data dengan wawancara mendalam dan focus grup discussion (FGD). Analisis data dengan hasil dari wawancara mendalam dan penyajian data dengan naratif. Pengabdian masyarakat ini dengan menggunakan alat dan bahan yaitu laptop, sound system, infocus dan poster piring antihipertensi.

\section{SASARAN}

Sasaran pada kegiatan ini adalah Kader Posbindu PTM dan Komunitas Protektor PTM di Desa Cikunir yang terdiri dari Posbindu Margamulya, Posbindu Gunung Kasur dan Posbindu Pamengpeuk dengan total kader sebanyak 16 Kader Posbindu PTM.

\section{E. TEMPAT DAN WAKTU}

Kegiatan ini berlokasi di Madrasah Pameungpeuk Desa Cikunir Kecamatan Singaparna Kabupaten Tasikmalaya. Waktu pelaksanaan kegiatan ini dilaksanakan pada hari Sabtu, tanggal 9 November 2019 pada jam 09.00-11 WIB.

Pada tahap perencanaan dimulai dengan penyusunan kepanitiaan, penyusunan Satuan
Acuan Penyuluhan (SAP), penyusunan anggaran kebutuhan alat dan bahan serta pembuatan jadwal kegiatan. Pada tahap pelaksanaan kader Posbindu PTM sangat antusias dalam kegiatan ini dan pada tahap evaluasi pelaksana kegiatan ini melakukan evaluasi pada pelaksanaan kegiatan ini dengan berdiskusi dengan anggota pelaksana kegiatan ini dalam penilaian faktor pendukung dan faktor penghambat dalam kegiatan ini

\section{F. PELAKSANA}

Pelaksana kegiatan ini terdiri dari ketua pelaksana dan anggota pelaksana. Ketua pelaksana adalah Wuri Ratna Hidayani. Anggota adalah mahasiswa Program Studi S1 Kesehatan Masyarakat antara lain Nurazijah, Lia Amalia, Ario Wahid Sauma dan Iqrar Yanwar Shobah.

Ketua pelaksana berperan dalam memimpin pelaksanaan kegiatan, bertanggungjawab dalam kelancaran kegiatan, pembicara dalam penyuluhan dan melakukan peragaan serta materi tentang media piring antihipertensi. Anggota I berperan dalam penentuan sampel dan menghubungi kepala desa, kepala RT dan RW serta tokoh masyarakat dalam perizinan kegiatan. Anggota II berperan dalam konsumsi pelaksanaan kegiatan ini dan membuat absen serta daftar hadir. Anggota III berperan dalam penyiapan alat dan bahan seperti sound system, infocus dan laptop. Anggota IV berperan dalam penyiapan media poster piring antihipertensi

\section{G. HASIL KEGIATAN DAN PEMBAHASAN}

Karakteristik subjek pengabdian masyarakat yaitu kader posbindu terdiri dari 8 kader dari Posbindu PTM Gunungkasur, 5 kader dari Posbindu PTM Margamulya dan 3 kader dari Posbindu Pamengpeuk. Berdasarkan umur proporsi terendah adalah umur 29 tahun 1 orang $(6,25 \%)$ dan proporsi tertinggi adalah umur 70 tahun 1 orang $(6,25 \%)$. Pendidikan subjek pengabdian masyarakat adalah S1 sebanyak 
1 orang $(6,25 \%)$, Diploma II 1 orang $(6,25 \%)$, dan SMA sebanyak 2 orang $(12,5 \%)$, SMP sebanyak 12 orang (75\%). Hasil pengabdian masyarakat ini kegiatan yang pertama hasil kegiatan penyuluhan faktor risiko penyakit tidak menular yaitu Kader Posbindu PTM dapat meningkat pengetahuannya tentang factor risiko penyakit tidak menular, Kader Posbindu PTM memahami pentingnya berperilaku hidup sehat sebagai upaya menghindari risiko penyakit tidak menular, Kader Posbindu PTM mensosialisasikan faktorfaktor risiko penyakit tidak menular kepada sasaran Posbindu PTM. Hasil kegiatan ini sejalan dengan teori Notoatmodjo (2010) menyatakan bahwa pengetahuan merupakan hasil dari proses tahu.. Berdasarkan teori ini sesuai dengan antusias kader Posbindu PTM dalam mengikuti penyuluhan dan mensosialisasikan pengetahuan yang diperoleh dari kegiatan ini kepada masyarakat. Pengabdian masyarakat ini sesuai dengan Indarjo (2019) upaya pengendalian penyakit tidak menular karena didukung oleh pengetahuan dan keterampilan kader Posbindu PTM baik melalui penyuluhan maupun pelatihan kader (Indarjo, 2019). Oleh karena itu perlu adanya peningkatan pengetahuan kader salah satunya penyuluhan faktor risiko penyakit tidak menular. Antusias kader juga seharusnya didukung oleh mitra dalam kegiatan ini yaitu pemerintahan Desa dan pihak Puskesmas Singaparna serta Dinas Kesehatan Kabupaten Tasikmalaya. Hasil kegiatan peragaan media piring antihipertensi yaitu pemahaman dan pengetahuan Kader Posbindu PTM tentang pentingnya media promosi kesehatan piring antihipertensi sebagai media untuk penyuluhan pentingnya pengelolaan pola makan bagi penderita hipertensi, Pengetahuan tentang gizi seimbang pada Kader Posbindu PTM dapat meningkat, Kader Posbindu PTM memberikan respon positif terbukti adanya tanya jawab tentang media piring antihipertensi, Kader Posbindu PTM PTM diharapkan dapat mengaplikasikan pola hidup sehat terutama pola makan yang sehat dengan pemenuhan gizi seimbang dan terampil dalam pengelolaan menu sehat gizi seimbang dalam pencegahan hipertensi. Hasil pengabdian ini sejalan dengan Yulyana (2018) yang menyatakan bahwa kader remaja posbindu PTM yang dilakukan pendampingan oleh mahasiswa dengan adanya terbentuknya media edukasi berupa filler mampu meningkatkan pengetahuan kader remaja dalam mengedukasi masyarakat dalam upaya penurunan penyakit PTM.

\section{H. KESIMPULAN DAN SARAN}

Pelaksanaan kegiatan penyuluhan faktor risiko penyakit tidak menular dapat meningkatkan pengetahuan Kader Posbindu PTM tentang penyakit tidak menular, jenisjenis penyakit tidak menular, faktor risiko penyakit tidak menular dan cara pencegahan penyakit tidak menular sehingga Kader Posbindu PTM dapat berperilaku hidup sehat, menghindari faktor risiko PTM, melakukan pencegahan penyakit tidak menular, mengembangkan media promosi kesehatan dalam pencegahan penyakit tidak menular, merencanakan penyuluhan serta konseling penyakit tidak menular bagi sasaran Posbindu PTM.

Selain penyuluhan pada kegiatan ini juga adanya sosialisasi dalam penggunaan media poter piring antihipertensi mensupport Kader Posbindu PTM dapat mensosialisasikan kepada sasaran posbindu PTM dalam upaya pencegahan hipertensi melalui media piring antihipertensi. Media tersebut diharapkan menjadi pedoman pengaturan pola makan bagi penderita hipertensi dan sasaran yang berisiko hipertensi. Dengan sosialisasi media piring antihipertensi ini kader dapat meningkatkan keterampilan Kader Posbindu PTM dalam upaya pencegahan dan penurunan kasus penyakit tidak menular khususnya hipertensi. Rekomendasi dalam kegiatan ini yaitu perlu adanya kerjasama dari ketiga Posbindu PTM dalam meningkatkan peran dan tupoksi sebagai kader serta bekerjasama dalam pembuatan media edukasi penyuluhan dan sosialisasi 
pencegahan risiko hipertensi dan penyakit tidak menular. Pihak mitra pengabdian masyarakat sebaiknya rutin dalam pembinaan kader dan mensupport dalam anggaran pelaksanaan serta adanya kebijakan-kebijakan dalam pengendalian PTM.

\section{DAFTAR PUSTAKA}

Dinas Kesehatan Provinsi Jawa Barat. 2013. Profil Kesehatan Provinsi Jawa Barat Tahun 2013. Dinas Kesehatan Provinsi Jawa Barat. Jawa Barat.

Pemerintahan Kecamatan Singaparna. 2014. Profil Desa Cikadongdong 2014. Tasikmalaya.

Indarjo, Sofwan; Hermawati, H; Nugraha, E. 2019. Upaya Pelatihan Pos Pembinaan Terpadu Penyakit Tidak Menular (Posbindu PTM) pada Kader Posyandu di Desa Kalikayen Kecamatan Ungaran Timur Kab Semarang. ABDIMAS 23 (2) (2019): 134-138

Kemenkes RI. 2014. Pos Pembinaan Terpadu Penyakit Tidak Menular. Ditjen Pengendalian Penyakit dan Penyehatan Lingkungan. Direktorat Pengendalian Penyakit Tidak Menular Edisi I Cetakan II

Notoatmodjo.2012. Promosi Kesehatan dan Perilaku Kesehatan.Jakarta : Rineka Cipta

WHO. 2017. Noncomunicables Disease Tersedia dihttp://www.who.int/mediacentre [Sitasi 30 September 2019]

Yulyana, Yana. 2018. Protector Jaten (Program Deteksi Dini dan Cegah Penyakit Oleh Remaja Jaten) Sebagai Upaya Peningkatan Partisipasi Remaja dalam Kegiatan Posbindu PTM di Dusun Jaten Yogyakarta. UGM Public Health Symposium

\section{J. DOKUMENTASI}
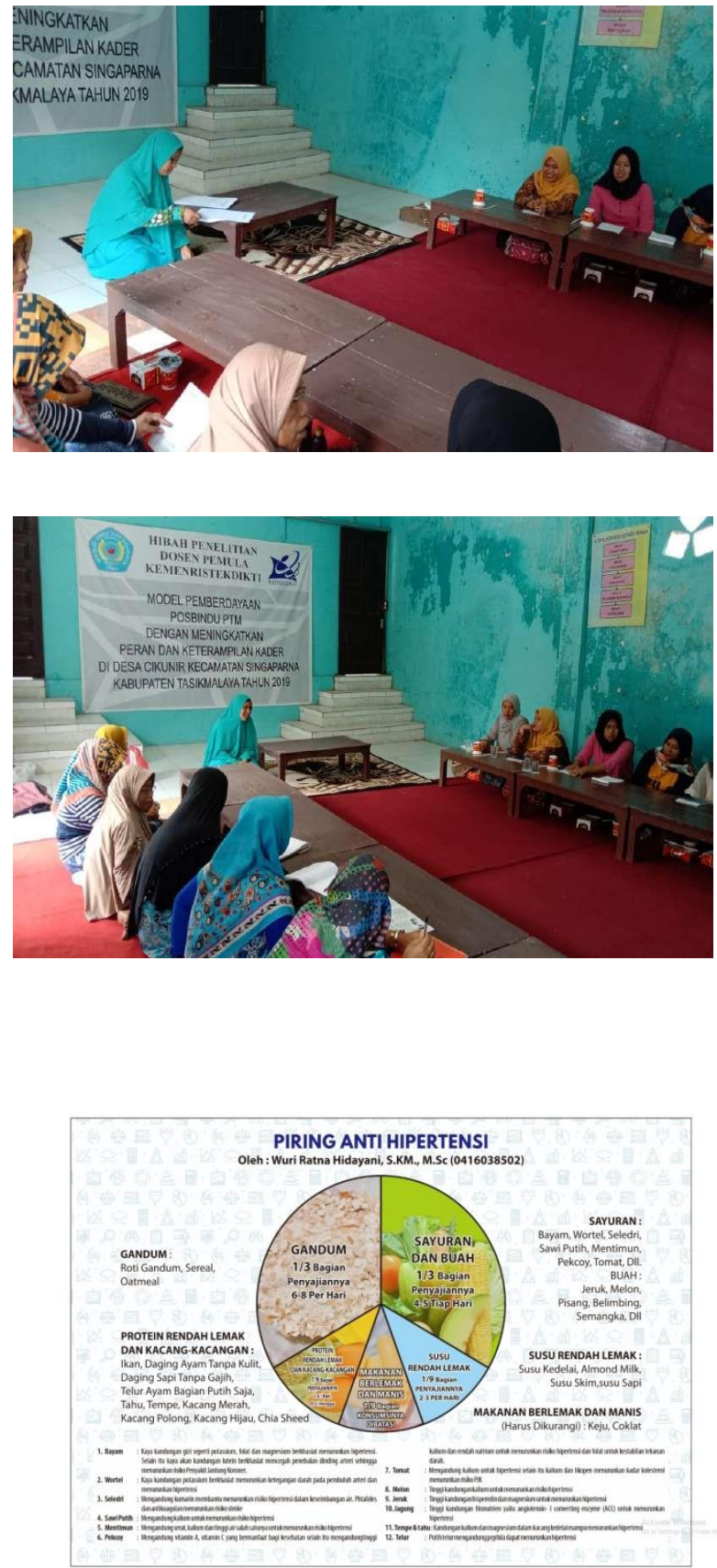